\title{
Performance Test of a Household Rocket Stoves Fired with Coconut Frond, Coconut Shell and Bamboo
}

\author{
Almuzakkir ${ }^{1}$, Muhammad $^{2}$, Adi Setiawan $^{3}$ \\ ${ }^{1}$ Post-graduate Program in Renewable Energy Engineering, Faculty of Engineering, Universitas Malikussaleh \\ ${ }^{2}$ Chemical Engineering Department, Faculty of Engineering, Universitas Malikussaleh \\ ${ }^{3}$ Mechanical Engineering Department, Faculty of Engineering, Universitas Malikussaleh
}

Corresponding Author: Adi Setiawan

\begin{abstract}
Fuel is something that is very important in everyday life. Almost every human being needs fuel to meet their needs and support their activities, for example cooking in household needs. Currently, fossil fuels or fuel oil (BBM) are still widely used to meet demand, however, it should be noted that fossil fuels or fuel oil (BBM) are non-renewable natural resources. The biomass rocket stove is one of the modern stove innovations that uses biomass energy as the main energy source. Rocket stoves are designed to increase fuel efficiency with thermal efficiency, a combination of the increased combustion efficiency and heat transfer associated with burning briquette fuel. The purpose of this research is to design and manufacture rocket stove fired with coconut and bamboo biomass for household needs as well as developing methods and equipment for performance testing of rocket stoves. In this study, several steps were carried out, including designing a rocket furnace, selecting biomass fuel and testing the performance of a rocket furnace. From the design of the biomass stove, it is noteworthy that the design with two holes makes the combustion air easily enters and makes combustion in the furnace more perfect and efficient. Water boiling test using three types of solid fuels with the cold start condition suggested that the highest thermal efficiency was coconut fronds with a value of $38 \%$ and the lowest thermal efficiency was found from coconut shell combustion, i.e. 22\%. During hot start test, the highest thermal efficiency was obtained from coconut fronds firing with a value of $41 \%$. Moreover, with simmer water boiling
\end{abstract}

test method, firing the rocket stove with coconut fronds showed the highest thermal efficiency with a value of $37 \%$.

Keywords: Rocket Stoves, Coconut Fronds and Shells, Bamboo, Thermal Efficiency, Water Boiling Tests

\section{INTRODUCTION}

Biomass energy is one of the many alternative energies that are continuously being used to reduce the use of energy derived from fossils such as gas, petroleum, and others. Firewood is one of the biomass energies with a calorific value of $4320 \mathrm{Kcal}$ per kg (Widawati, 2019). The conventional stove with the main energy source is firewood as the main tool in cooking activities because besides it does not require money to get it and also the distribution of LPG gas which is scarce and limited in quantity.

The use of conventional stoves, also called three stone stoves, is considered less efficient because it uses firewood which can cause the forest to become deforested. Converting a conventional stove is needed to become a biomass stove model that has a higher level of efficiency. Traditional stoves have many problems that occur in igniting the stove. Among them are the first, which is not easy to stabilize the size of the furnace flame, especially at the beginning of ignition, so it takes a few minutes to stabilize the flame. The second is that the 
use of a furnace requires additional energy or kerosene as an ignition to get the flame. Third, it is difficult to extinguish the flame (Alvenher, 2012).

The biomass rocket stove is one of the modern stove innovations that uses biomass energy as the main energy source. Rocket stoves are designed to increase fuel efficiency with thermal efficiency, a combination of the increased combustion efficiency and heat transfer associated with burning briquette fuel (Widawati, 2019).

The working principle of a rocket stove is that this stove is made of two horizontal tubes to place wood fuel and an air opening at the bottom, which is connected to a vertical tube as a heat sink so that the stove will be shaped like an "L". When the stove is on, the fire gets enough oxygen because of the air openings at the bottom of the tube. The heat will be channeled through the vertical tube and out at the top end. So that this stove will produce more efficient combustion because all the wood will burn completely and will produce less smoke than conventional stove stoves (Khan, 2016).

The biomass stove has maximum thermal efficiency and has better performance when compared to the average thermal efficiency value of $17.9 \%$ for traditional clay stoves (Ayo, 2009). In gasification stoves in terms of burning almost smokeless under certain conditions (Bhattacharya, 2009). With the government policy to increase fuel prices, it is precisely the stove that uses wood fuel as the most efficient alternative for consumers in the midst of an economic downturn. For this reason, the use of residual waste biomass such as wood branches, sawdust, wood and plywood the utilization of waste residues that disturb the environment and aesthetics will be reduced so that it can reduce environmental pollution, and increase the added value of waste that normally just thrown away. It is hoped that the use of rocket stove biomass stoves will reduce the use of fossil fuels which are increasingly running out. The use of rocket stove with raw materials from wood waste is very appropriate for the middle-down economic community.

Biomass waste which is used as an energy source is generally biomass which has low economic value or is waste after its primary product has been taken. Each biomass waste has the potential to be used as an alternative fuel. This can be seen from the calorific value contained in the biomass waste. Indonesia is an agricultural country where the potential for biomass waste will always increase.

The huge potential of biomass waste as an alternative energy source, it is possible to socialize the use of biomass waste as an alternative energy. Reducing fossil fuel consumption in accordance with the national energy management blue print 2005-2025, Indonesia's policy has a target, one of which is to increase renewable energy (biomass energy use) to $15 \%$ of the total use of energy sources (Riseanggara, 2008).

This investigation aims to find out the higest thermal efficiency that can be performed by our purposely built Rockets stove. The stove is designed to the Seed of biomassa cook stove for rural area. There were Three types of biomass wastes used as fuel for this stove including coconut frond, coconut shell and bamboo.

\section{METHODS}

The utilization of biomass waste for testing the rocket furnace is designed in this study to be carried out with the first step, namely Preparation of biomassa waste raw material, determination of parameter, making biomassa stoves, biomassa stove calculation, testing of biomassa stoves and biomassa stove performance analysis. The thermal energy produced by the rocket furnace will be used for heating water and the thermal efficiency, combustion efficiency, particulate matter (PM) and exhaust emissions will be calculated. The rocket furnace set up is designed to comply with the Indonesian National Standard (Anonim, 2013). 
The tools and materials used in this study consist of rocket furnace equipment, testing equipment and biomass waste materials, Aluminum Pans, Analytical Scales, Thermocouple, Oven, Water, Coconut midrib, Coconut shell and Bamboo.

In this article, testing of a biomass rocket stove is carried out using the water boiling test (WBT) method. This WBT method has three stages of testing, namely cold start, hot start, and simmer.Cold start, namely testing until the water reaches boiling temperature starting from the furnace and water in cold conditions (room temperature). Hot start start, which is the test carried out immediately after the first phase with a hot stove and filled with water at room temperature. Done until the water boils. Simmer is done after the second phase with the furnace and water in a hot state (Andi et al, 2013).

The first work step is to prepare a pot containing 1 liter of water. Then fill the biomass fuel in the form of coconut leaves into the stove as much as $1 \mathrm{~kg}$. Prepare a piece of paper to be turned on as an initial trigger in start-up. Prepare a stopwatch to calculate the total operating time. If all the equipment to support the research process is available, the next step is to turn on the stove, observe the start-up process if it is perfect. Then in the water boiling test (WBT) method, the first is cold start by heating water at room temperature to boiling starting from the pan at room temperature, then the hot start method is carried out immediately after the cold start phase with a hot furnace. and fill with water to room temperature and then the simmer method is carried out by putting it in the hot water pan after the hot start phase and the furnace is also hot. Then the above work steps are repeated with other biomass fuels, namely coconut shell and bamboo.

\section{RESULTS AND DISCUSSION}

In this study, several stages were carried out, namely designing a rocket furnace, selecting biomass fuel and determining the specification of a rocket furnace. The design of the rocket furnace uses aluminium with a height of $0.575 \mathrm{~m}$ and a width of $0.346 \mathrm{~mm}$. The furnace hole size is $0.115 \times 0.115$. Each mass of raw material used is $1 \mathrm{~kg}$ of teak wood, wood twigs and plywood waste. The furnace is made by arranging aluminium plates into a rocket furnace.

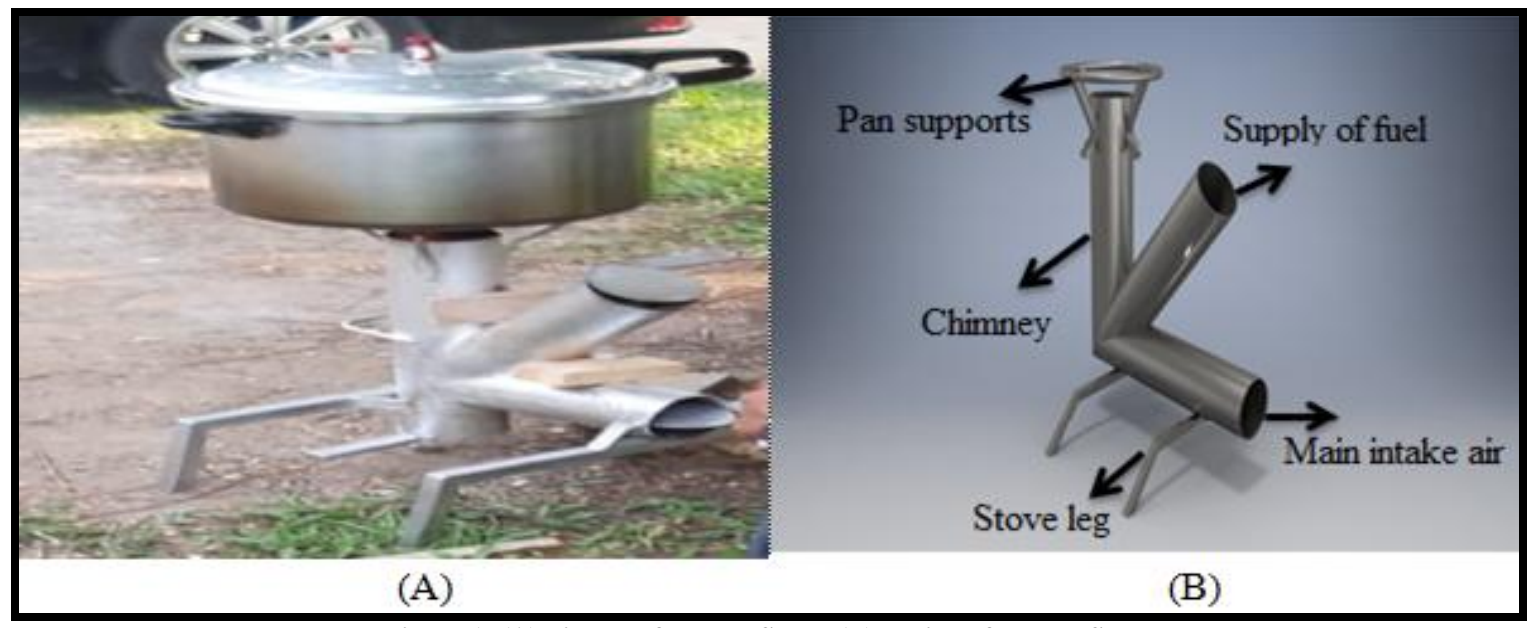

Figure 1: (A) Picture of Rocket Stove, (B) Design of Rocket Stove

The selection of biomass fuel in this study uses coconut fronds, coconut shells and bamboo. Each biomass fuel used has a different heating value, causing a difference in the rate of combustion for each type of fuel. The difference will be a reference for future researchers to maximize one of the 3 (three) biomass fuels in this study.

On the environmental side, the selection of biomass fuel will reduce the 
waste of biomass around the environment so that it can reduce the impact of damage to the environment.

Biomass stoves are designed according to Indonesian national standards on biomass stove performance (Anonim, 2013). Design of Rocket Stove can be seen in Figure 1 (B).

In Figure 1, a prototype biomass stove has been designed which has efficient specifications with a large fuel supply so that the fire that will be produced will also be large. Then the holes for the intake air have 2 holes so that the oxygen in the stove can keep the fire burning. Chimneys are used to convey smoke to emission test kits. This biomass stove is also equipped with a collection of ash resulting from burning fuel. The biomass stove emission test tool can be seen in Figure 5.

Based on the Indonesian national standard (Anonim, 2013), a furnace is declared to have passed the specific fuel consumption test of a maximum of 1 $\mathrm{kg}$ /hour, a furnace is declared to have passed the combustion efficiency test if the $\eta c$ value is at least 0.96 , the furnace is declared to have passed the thermal efficiency test if the efficiency test results meet the minimum value $20 \%$, the biomass stove is declared to have passed the $\mathrm{CO}$ emission test if the $\mathrm{CO}$ emission does not exceed $67 \mathrm{~g} / \mathrm{kg}$ of consumed fuel and the biomass stove passes the PM 2.5 emission test if the PM 2.5 emission is not more than $1500 \mathrm{mg} / \mathrm{kg}$ of fuel consumed

\section{Water Boilling Test}

Testing of the biomass rocket stove was carried out using the water boiling test (WBT) method. This WBT method has three stages of testing, namely cold start, hot start, and simmer. For the test result data, cold start is presented in Table 1 .

Table 1: WBT Test Results at Cold Start

\begin{tabular}{|c|l|c|c|c|c|}
\hline & & \multirow{2}{*}{ High Power Test (Cold Start) } & Units & \multicolumn{3}{|c|}{ Type of Fuel } \\
\cline { 4 - 6 } No & Coconut Frond & Coconut Shell & Bamboo \\
\hline 1 & Time to Boil Pot \#1 & min & 9 & 8.33 & 7 \\
\hline 2 & Burning Rate & $\mathrm{g} / \mathrm{min}$ & 11 & 22 & 22 \\
\hline 3 & Thermal Efficiency & $\%$ & 38 & 22 & 28 \\
\hline 4 & Specific Fuel Consumption & $\mathrm{g} /$ liter & 70 & 139 & 77 \\
\hline 5 & Temp-Corrected Specific Energy Cons & kJ/liter & 1342 & 2600 & 1398 \\
\hline 6 & Firepower & Watts & 3146 & 6545 & 6369 \\
\hline
\end{tabular}

Based on Table 1, it can be seen the comparison of the results of the water boiling test results against three types of fuel at the cold start stage. Of the three types of fuel used the highest thermalefficiency was coconut fronds with a value of $38 \%$ and the lowest thermal efficiency value for coconut shell fuel. However, the fastest fuel that can boil one liter of water is bamboo in 7 minutes, coconut shell 8.33 minutes and coconut midrib for 9 minutes.
Based on Table 2, it can be seen the comparison of the results of the water boiling test results against three types of fuel at the hot start stage. Of the three types of fuel used, the highest thermal efficiency was coconut fronds with a value of $41 \%$ and the lowest thermal efficiency value for coconut shell fuel, namely $18 \%$. However, the fastest fuel that can boil one liter of water is bamboo in 3 minutes, then coconut shells for 5.33 minutes and coconut fronds for 10 minutes.

Table 2: WBT Test Results at Hot Start

\begin{tabular}{|c|l|c|c|c|c|}
\hline \multirow{2}{*}{ No } & High Power Test (Hot Start) & Units & \multicolumn{3}{|c|}{ Type of Fuel } \\
\cline { 4 - 6 } & & & Coconut Frond & Coconut Shell & Bamboo \\
\hline 1 & Time to Boil Pot \#1 & gin & 10 & 5.33 & 3 \\
\hline 2 & Burning Rate & g/min & 9 & 37 & 51 \\
\hline 3 & Thermal Efficiency & $\%$ & 41 & 18 & 33 \\
\hline 4 & Specific Fuel Consumption & g/liter & 58 & 147 & 76 \\
\hline 5 & Temp-Corrected Specific Energy Cons & kJ/liter & 1135 & 2755 & 1568 \\
\hline 6 & Firepower & Watts & 2510 & 11032 & 1440 \\
\hline
\end{tabular}


Almuzakkir et.al. Performance test of a household rocket stoves fired with coconut frond, coconut shell and bamboo

Table 3: WBT Test Results in the Simmer State

\begin{tabular}{|c|l|c|c|c|c|}
\hline \multirow{2}{*}{ No } & Low Power Test (Simmer) & \multirow{2}{*}{ Units } & \multicolumn{3}{|c|}{ Type of Fuel } \\
\cline { 4 - 6 } & & & Coconut Frond & Coconut Shell & Bamboo \\
\hline 1 & Burning rate & $\mathrm{g} / \mathrm{min}$ & 7 & 22 & 15 \\
\hline 2 & Thermal efficiency & $\%$ & 37 & 25 & 34 \\
\hline 3 & Specific fuel consumption & $\mathrm{g} / \mathrm{liter}$ & 127 & 280 & 290 \\
\hline 4 & Temp-corrected specific energy cons. & kJ/liter & 2245 & 4951 & 4950 \\
\hline 5 & Firepower & Watts & 2088 & 6420 & 4226 \\
\hline 6 & Turn down ratio & -- & 2 & 1 & 2 \\
\hline
\end{tabular}

Based on Table 3, it can be seen the comparison of the results of the water boiling test results against three types of fuel at the simmer stage. Of the three types of fuel used, the highest thermal efficiency was coconut fronds with a value of $37 \%$ and the lowest thermal efficiency value for coconut shell fuel, namely $25 \%$. However, the fuel with the highest combustion rate is coconut shell $22 \mathrm{~g} /$ minute and the highest combustion rate is coconut frond 7 $\mathrm{g} /$ minute.

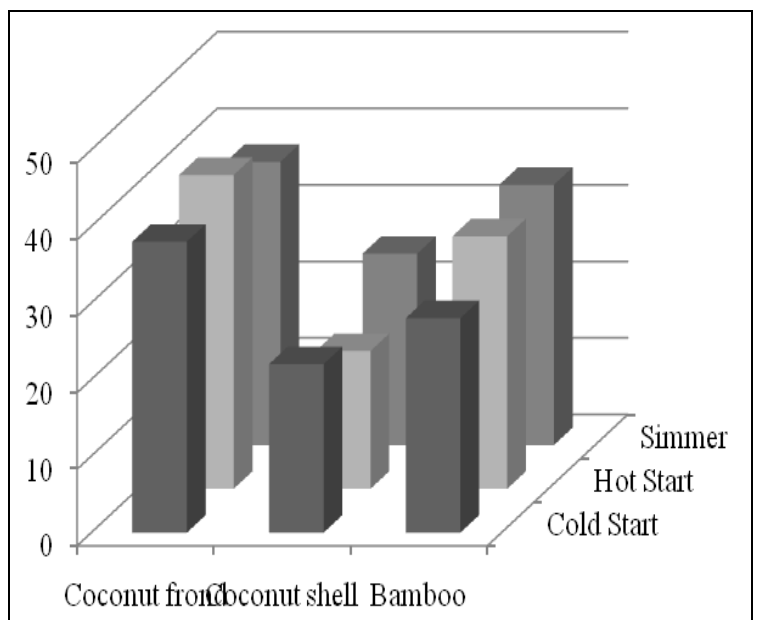

Figure 2. Thermal Efficiency Using the WBT Method with Three Types of Biomass Waste

Based on the graph in Figure 1In the cold start state, the greatest thermal efficiency was obtained from coconot frond biomass waste, namely $38 \%$, while the smallest thermal efficiency was in coconut shell biomass waste, which was $22 \%$. In the hot start state, the greatest thermal efficiency is obtained from coconot frond biomass waste, which is $41 \%$, while the smallest thermal efficiency is coconut shell biomass waste, which is $18 \%$. Then, in the simmer state, the greatest thermal efficiency is obtained from coconot frond biomass waste, namely $37 \%$, while the smallest thermal efficiency is coconut shell biomass waste, which is $25 \%$.

\section{CONCLUSION}

Investigation on the performance of a household rocket stove has been performed using water boiling test method. Three types of fuels have been used including coconut frond, coconut shell and bamboo. Water boiling test with cold start condition indicated that the highest thermal efficiency was found from coconut fronds firing with a value of $38 \%$, while the lowest thermal efficiency was from coconut shell combustion (i.e. 22\%). During hot start condition, the highest thermal efficiency was obtained also from coconut fronds with a value of $41 \%$ and the lowest thermal efficiency was coconut shell, i.e. $18 \%$. Furthermore, at simmer test, the highest thermal efficiency was also coconut fronds with a value of $37 \%$ and the lowest thermal efficiency value was coconut shell i.e. $25 \%$.

\section{REFERENCES}

1. Alvenher, E. (2012). Pengaruh Lebar Celah dan Tinggi Selimut Panci Terhadap Kinerja Tungku Rumahan. (Skripsi). Jurusan Teknik Pertanian. Fakultas Pertanian. Universitas Lampung. Bandar Lampung.

2. Andi Taufan, Novrinaldi, Umi Hanifah. 2013. Rancangbangun dan Pengujian Tungku Berbahan Bakar Gas Untuk Industri Tahu Tradisional Berbasis Produksi Bersih. AGRITECH. Vol 33. Balai Besar Pengembangan Teknologi Tepat Guna (BBPTTG) - Lembaga Ilmu Pengetahuan Indonesia (LIPI).

3. Anonim. SNI 7926:2013. (2013). Kinerja Tungku Biomassa. BSN.

4. Ayo, S. A. (2009). Design, Construction and Testing of an Improved Wood Stove. Journal Mechanical Engineering. Federal University of Technology Minna. Nigeria. Volume 13. 
5. Bhattacharya, S. C. (2009). A Study on Improved Institutional Biomass Stove. Journal Energy Program. Asian Institute of Technology. Klong Luang. Pathumthani. Thailand.

6. E. Widawati, S. Octaviani, L. Lauwrence, L.R. P. Sudharma. (2019). Kompor Roket Berbahan Bakar Briket Biomassa. Seminar Nasional AVoER XI 2019 Fakultas Teknik Universitas Sriwijaya.

7. Khan, Sabrina., et al. (2016). Development of Portable Rocket Stove and Performance
Evaluation. Journal of Enginnering and Techonolgy. 03(12):3644.

8. Riseanggara, Rayadeyaka Raditya. (2008). Optimasi Kadar Perekat Pada Briket Biomassa. Skripsi. Fakultas Teknologi Pertanian, Institut Pertanian Bogor. Bogor.

How to cite this article: Almuzakkir, Muhammad, Adi Setiawan. Performance test of a household rocket stoves fired with coconut frond, coconut shell and bamboo. International Journal of Research and Review. 2021; 8(1): 5964. 